\title{
W.E UPJOHN INSTITUTE
}

FOR EMPLOYMENT RESEARCH

Upjohn Institute Press

\section{Introduction}

John A. Turner

AARP Public Policy Institute

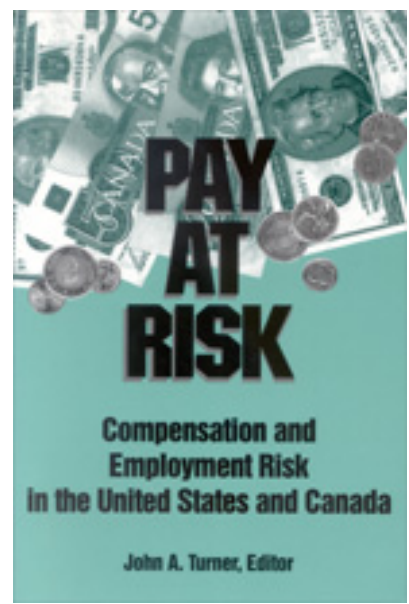

Chapter 1 (pp. 1-18) in:

Pay at Risk: Compensation and Employment Risk in the United States and Canada

John A. Turner, ed.

Kalamazoo, MI: W.E. Upjohn Institute for Employment Research, 2001

DOI: 10.17848/9780880994194.ch1

Copyright @2001. W.E. Upjohn Institute for Employment Research. All rights reserved. 


\title{
1 \\ Introduction
}

\author{
John A. Turner
}

Major changes have occurred in the U.S. labor market over the past few decades. The rate of growth of real earnings decreased and even turned negative for periods, and earnings inequality has increased. Many observers also believe that earnings and job instability have increased.

While the decline in real earnings growth and increase in inequality are well documented, less is known about changes in earnings and job instability. Do workers bear more employment-related financial risks than in previous decades? Have work hours and pay become increasingly sensitive to the labor market? Have labor market risks in North America been shifted from employers to workers? Has there been a decline in the U.S. version of the welfare state (where employers play a relatively large role in providing social welfare benefits), just as the welfare state has declined in Europe?

\section{CANADA-UNITED STATES COMPARISONS}

Comparing Canadian and U.S. labor markets yields insights about the risks workers bear. Labor markets in the two countries have many similarities, although the relatively small Canadian economy is less than 10 percent as large as that of the United States. The proximity and dominant size of the United States cause substantial economic, cultural, and intellectual influences on Canada, and U.S. firms own a significant proportion of Canadian industry. Even before the CanadaUnited States Free Trade Agreement, the precursor to the North American Free Trade Agreement (NAFTA), the United States and Canada exchanged more goods and services than any other two countries in the world. Each country is the largest trading partner of the other. 
Given the similarity of the two countries and their interconnections, one would expect Canadian employers to act much like their American counterparts, especially since firms from both countries often compete in the same markets using similar technologies (Verma and Thompson 1988). The similarities in the two countries and their integration through trade make it likely that the policy experiences of one have relevance for the other (Gunderson, Hyatt, and Pesando 1996).

This chapter provides an introduction to some of the conceptual issues concerning compensation risk bearing by workers in labor markets. The following discussion provides background and is more abstract than the other chapters, which discuss the evidence concerning changes in risk bearing in particular aspects of compensation. This chapter provides a framework for thinking about some of the issues raised in the more applied chapters, and it concludes with an overview of the remainder of the book.

\section{COMPENSATION RISK BEARING IN LABOR MARKETS}

\section{Conceptual Issues}

Risk is an element of all aspects of employee-employer relationships, including pay rates, working time, and employment security. The allocation of risk bearing determines the extent to which risks are borne by workers, by firms and their stockholders, and by government.

Labor market risks may pose serious problems for some workers. Many workers have mortgages and large financial commitments for rearing and educating children. Fixed financial commitments become problems for workers who face decreases in income due to unemployment or decreased work hours, or increases in expenses due to medical bills not covered by health insurance.

Employers face risks affecting their demand for labor due to changes in their factor markets, technology, exchange rates, international competition, domestic competition, the legal environment, tax policy, and macroeconomic conditions affecting demand for their product. Other demand-side factors that may affect workers' risk include 
factors affecting the institutional setting in which wages are set. These factors include employer size, collective bargaining status, and legal constraints (e.g., mandatory notice for layoffs).

Workers also face health-related risks that affect their labor supply, including illness, disability, declining ability to work at older ages, and early death with surviving dependents to provide for. These risks can be insured against through health insurance, disability insurance, early retirement benefits, and life insurance. Workers also face the opposite possibility of extended longevity, which brings the risk of outliving their resources, a risk that can be insured against through annuitization of retirement income.

Workers obtain insurance against risks from social insurance through government (such as social security), private insurance through employers and personal purchase, and insurance against labor demand shifts through employers and their stockholders, who may bear some labor demand risks for workers.

Risks due to the cost of health care are generally unrelated to work, but in the United States, these risks have most often been insured through health insurance provided by employers. In Canada, they have been insured through mandatory universal health insurance.

Long-term job commitments by employers provide a form of earnings insurance to workers. In spite of fluctuations in labor demand, these arrangements may benefit both workers and firms. Both workers and firms more willingly invest in workers' job skills when there is a long-term commitment. Long-term employment reduces recruiting, hiring, and training costs for employers.

Long-term job commitments by employers benefit workers in that they derive utility from the security of income, presumably accepting a lower wage in exchange for greater security. This wage reduction may be offset to some extent by higher worker productivity due to greater investments in job-specific human capital being made when there are long-term job commitments. However, if workers give up potential opportunities associated with job mobility when they enter a job that penalizes quitting, some workers may require a wage premium rather than pay a compensating differential. There is a trade-off between job security with a penalty for job change versus job insecurity with the upside potential of changing to a better job. Thus, workers who expect to have the possibility of large wage gains from job mobility will not 
value as highly the benefits of job security and will seek jobs that do not penalize mobility.

\section{Policy Issues}

Public policy may affect worker risk bearing. Public policy that reduces worker risk bearing may reduce work incentives, in turn reducing the flexibility of the economy and its ability to produce new jobs. Thus, public policy that increases the costs of laying off workers, such as by mandating notice of a certain length of time or mandating severance pay, may reduce risk for workers already employed but also reduce hiring by firms. Public social insurance programs may increase risk taking since they reduce its negative consequences. For example, to maintain utility constant, a worker would be willing to accept a lower level of job security if unemployment insurance is exogenously increased.

In addition, social insurance programs that provide income contingent on not working, such as unemployment insurance and old age retirement benefits, may reduce labor supply. Due to moral hazard, unemployment insurance shifts risk in labor markets toward unemployment and away from variability in wage rates. Thus, social insurance programs may increase flexibility in the labor market and may affect the form that flexibility takes. They may reduce labor supply, and the taxes to finance social insurance may strengthen that effect.

Conversely, some government policies may increase the flexibility of the labor market but at the expense of increasing risks to workers. When first elected in 1979, the British Conservative party had a stated aim of making the labor market more flexible (Millard 1997). It did this by passing legislation that reduced employment protection, eliminated the minimum wage, reduced regulations governing who could or could not be employed in various jobs, and reducing the power of unions. The length of time an employee must work before being able to take his employer to court for unfair dismissal was increased from six months to two years. New laws reducing the power of unions included a law that made it illegal for employers to refuse to hire someone because of not being a union member. 


\section{Theoretical Issues}

One measure of risk is the variability in employee compensation around its expected value. This measure incorporates variability both in hours worked and in the compensation rate. Thus, it incorporates unemployment, reduction in overtime, working short hours, loss of paid hours due to ill health, variability in wage rate, and variability in nonwage compensation. This measure is incomplete, however, in that it does not cover some types of risk that pensions and health benefits insure against.

A standard decomposition of variability in earnings for an individual into permanent and transitory components is as follows:

$$
Y(t)=u+v(t)
$$

where $Y$ is the $\log$ of annual earnings of individual $i$ in year $t ; u$ is the logarithm of permanent earnings of the individual, which does not vary with respect to time; and $v$ is transitory earnings that vary over time (Gottschalk and Moffitt 1994).

A different measure of the risks workers face is variations in the level of their consumption. For workers with little liquid savings, this measure of risk is affected by variation in both total compensation and in uninsured medical expenses. This book does not use this measure but focuses instead on more traditional measures of risk that are tied directly to labor market outcomes.

Demand-side risks can be divided into three categories.

1) Macroeconomic risk: the effects of macroeconomic fluctuations on demand for the firm's product.

2) Microeconomic risk: risks specific to the firm, industry, or region affecting demand for the firm's product.

3) Implicit contract risk relating to the firm's reaction function to macroeconomic and microeconomic risk, including changes in the insurance that firms provide against demand risk. Supplyside risk includes changes in the types of insurance the firm provides against risks, for example, pensions, health insurance, and disability insurance. 


\section{Risk bearing by firms}

Firms have two considerations in designing efficient compensation contracts: incentives and risk allocation. Some employers may prefer to link pay tightly to performance because that may lead to higher productivity. It will also, however, give workers more-variable income. Insurance that cushions reductions in earnings will inevitably affect workers' decisions and behavior. Efficient labor contracts must balance risk bearing and incentives in labor markets.

A fundamental issue in determining worker-firm risk bearing is which party bears risk more efficiently, and this depends partly on which party can reduce risk through diversification at the lowest cost. Competitive labor markets equilibrate, with the party bearing risk being the one that can most cheaply do so. Both employers and employees may shift risks to insurance companies or the government. The degree to which a particular employer can pass risk back to workers is limited by the extent to which workers have the option to work for other employers that offer a better mix of risk bearing and compensation.

Employers bear risks, but the theory of compensating differentials suggests that workers pay for this through reduced wages. The implicit payments by workers inherent in reduced wages are equivalent to insurance premiums. Thus, firms with a higher probability of layoff must pay higher wages to compensate workers for this risk (Topel 1984a).

Risk bearing by employers also occurs through the implicit contract in which the employer agrees to bear some risks concerning workers' wages, hours, and employment under varying demand and profitability. Implicit (and explicit) contracts allocate risks between workers and firms, but the contracts themselves have risks for workers. An employer may break the contract, although at a cost to his reputation in the labor market.

Risk bearing is likely to vary among firms. Firms facing different labor market conditions and different financial status may adjust to shocks in different ways. Risk bearing by firms is positively correlated with firm size, due to economies of scale in managing risk bearing and the ability to diversify. Large, diversified firms may stockpile workers, absorbing transitory shocks by reducing capital expenses and reducing 
profits. A large firm can diversify risks more easily than can a worker, whose earnings capacity is the main component of his income portfolio. Large firms can bear risks less expensively than small firms because they have a large enough risk pool of workers that they can self-insure. By insuring most or all of their workers, large firms diminish adverse selection.

\section{Employers' short-term adjustment strategies}

Firms face fluctuations in demand for their products, but workers want stable income. In order to adjust to demand shocks, firms can reduce their labor costs. They can do so by encouraging early retirement or by reducing the hours of workers. The greater is voluntary worker turnover and retirement, the less is the risk of job insecurity due to layoffs.

An aging workforce may have a positive effect on job security because there would be greater flexibility due to retirements. A labor force with a high proportion of young workers would also be more flexible because there would be greater turnover due to the relatively high turnover of young workers. The demographic composition of the labor force thus may affect the extent of job risk workers face. A middle-aged worker would face less job insecurity in a firm with a high proportion of its employees being young or being near retirement. Thus, there may be an increase in job insecurity in the United States and Canada because the large baby boom cohort is middle aged, and there are relatively few younger and older workers.

Employers can reduce fluctuations in employment by increasing or reducing overtime or short time. An alternative approach is to hire temporary employees during periods of peak demand. Hiring temporary employees may help preserve the job stability of long-term employees. Abraham and Houseman (1993) suggested that having broadly trained employees who can be transferred into the positions of workers who are quitting or retiring is another form of short-term adjustment.

For several reasons, firms may prefer layoffs to reducing hours. With layoffs, they can economize on fixed costs of employment, such as providing health insurance for their employees. With layoffs and experience-rating of unemployment insurance premiums, the employer's future costs increase. Because experience-rating is less 
than perfect, however, unemployment insurance may provide a way of shifting costs to other employers.

Abraham and Houseman (1993), however, argued that adjustments to varying labor demand through hours worked are superior to adjustments of employment, especially when the varying demand is cyclical. Employment adjustments entail more fixed costs (e.g., subsequent hiring costs) than do hours adjustments.

The extent to which firms adjust their labor demand by hiring and firing workers is affected by the fixed costs they face for hiring and firing, including the costs of training workers. Millard (1997) modeled labor market flexibility as depending on the fixed costs employers pay when creating or destroying jobs. An increase in fixed costs of hiring and firing leads to greater average hours worked, lower employment, and thus more use of full-time workers and less of part-time workers. Advance notice and severance pay provisions for layoffs are an aspect of fixed costs.

Employers can adjust compensation by reducing wages, reducing bonuses, and reducing nonwage compensation. In Japan, a fairly large percentage of pay in large firms is received through twice-yearly bonuses. Fluctuations in bonuses allow Japanese firms to maintain a stable workforce in the face of fluctuating demand. Small fluctuations in pay in the United States can occur through profit-sharing plans, where the employer does not commit to regular contributions but only contributes depending on the profit received by the firm.

To the extent that wages and compensation are inflexible downwards, more of the adjustment in labor demand will occur through changes in hours, including short-time and layoffs. Downward flexibility in wages requires renegotiating wage contracts. For reasons that are not well understood, it appears to be difficult to renegotiate wage contracts, which inhibits wage flexibility. Thus, when negative productivity shocks occur, adjustments tend to be made through hours of work rather than through wages.

Because of downward nominal wage rigidity, it may be easier to adjust real compensation during periods of inflation when real compensation automatically declines in the absence of action taken by employers.

Risk-averse workers are not indifferent to these options and would presumably prefer small compensation cuts or temporary layoffs to job 
loss, but, with unemployment insurance, they would prefer layoffs to large compensation cut. The provision of more generous unemployment insurance benefits increases the likelihood that employers will respond to adverse demand shocks with layoffs (Feldstein 1976; Topel 1984b). Eberts and Stone (1992) found that employers in the United States initially adjusted employment rather than wages in response to economic disturbances.

If they can cheaply store their product, firms can continue production at a constant level and adjust to a decline in demand that is expected to be temporary by stockpiling their product. With the development of just-in-time delivery, resulting in less stockpiling of inventory, there may be greater sensitivity of labor demand to product demand. In most modern economies, however, labor demand is closely tied to product demand. When labor demand falls, a decline in pay from a job could provide a buffer that reduces the risk of layoff.

Shocks to labor demand can be borne by stockholders. The extent to which they are borne by stockholders depends in part on the willingness of stockholders to do this and in part on the level of profits. Gordon (1982) hypothesized that the larger share of nonlabor income in Japan than the United States helps explain how large Japanese firms can offer their employees employment stability.

The apparent increase in job instability in the United States, however, has occurred at the same time that profits have grown relative to GDP. This pairing of events raises the question, have stockholders found it profitable to shift risk to workers? At the same time, have other factors (such as increased competition) reduced the level and stability of profits for some firms, reducing their ability to bear risks for workers?

There is a trade-off between volatility in compensation and volatility in employment. However, to the extent that real wages fall as an adjustment to a decline in demand, some workers may voluntarily quit. Workers who are laid off or quit may adjust by migrating to a different part of the country where they view their prospects to be more favorable, although this is done mostly by young or highly skilled workers. Thus, it may be more difficult for older workers to adjust to an increase in job insecurity than for younger workers because the costs of geographic mobility tend to be greater for older workers. 


\section{THE APPROACH OF THE BOOK}

The primary question this book addresses is as follows:

Are U.S. and Canadian workers bearing greater financial risk related to employment than in the past? This question provides the book's unifying theme, with the emphasis being on explaining changes in risk bearing. The approach used to address this question involves three further questions:

1) Do U.S. workers bear greater financial risks than Canadian workers?

2) Do the trends in risk bearing in the two countries differ?

3) What should be the policy responses in Canada and the United States?

To answer these questions, we examine changes in the variability in compensation, hours and employment, and changes in employee benefits and labor market programs. Each chapter discusses, as relevant, changes that have occurred in the United States and Canadian economies, theoretical issues, the economic literature relating to those changes and risk bearing, and the policy issues and implications. Taking a broad perspective, the book synthesizes research on risk bearing in various aspects of compensation, where previously changes in risk bearing have been discussed in isolation.

\section{OUTLINE OF THE BOOK}

\section{Risks to Wages: The Traditional and Contingent Workforces}

\section{Chapter 2: Wage and job risk for workers}

Aspects of job insecurity include the duration and incidence of unemployment, involuntary nonstandard work, and short-tenure jobs. Chapter 2 examines the question, has worker risk concerning hours, wages, and employment increased in traditional employment relationships in the United States and Canada? Some analysts have suggested 
that workers have less job security than in the past because of rapidly changing technology and, to a lesser extent, growing international trade. The result has been downsizing by firms, flattening of management structures with layoffs of middle management, and fewer manufacturing jobs. Has the implicit contract between workers and firms changed so that firms no longer promise the degree of job security they once did?

Aggregate U.S. labor market statistics, however, indicate little overall increase in job instability. Job instability (measured by median completed tenure, estimated retention rates, and job turnover) has been stable or increased for much of the labor force and decreased for other parts of the labor force.

Job insecurity, however, has increased for older males. Median tenure for males in age groups above age 40 has declined considerably. Median tenure declined in all educational categories for this age group, and other measures of job stability for this age group also declined.

While unemployment rates have decreased to historic lows for some groups, the proportion of displaced workers that are white collar has increased. Perhaps connected to the pattern of job instability by age and by being a white-collar worker; long-term unemployment (longer than 15 weeks) has risen as a percentage of total unemployment, because it is more difficult for this group to find new employment.

Job insecurity is particularly serious for midcareer workers age 40 and older. These workers have financial responsibilities for families, and because of their accumulation of firm-specific human capital, the wage loss from a layoff and subsequent hire by a different employer is greater for a worker in his or her peak earnings years than it is earlier in life.

\section{Chapter 3: Risk in employment arrangements}

Nonstandard work arrangements include contingent, alternative, and part-time workers. This chapter indicates that, relative to the size of the labor force, the growth of the contingent and alternative workforce has been slight.

Many workers, however, do not have the type of employment relationship they prefer. While some workers prefer the flexibility of nonstandard work, roughly half of contingent workers surveyed indicated 
that they preferred noncontingent work arrangements. Houseman (1995) noted that the rate of involuntary part-time employment, those who desire full-time work but cannot find it and those temporarily put on short-time work by their employer, has increased. While many think self-employment has increased due to downsizing and is itself a symptom of increased job insecurity, labor statistics indicate otherwise. The percentage of workers who are self-employed has been fairly stable since 1980 (Bregger 1996).

An unanswered question related to this chapter is, has the cost of providing health and pension benefits in the United States caused firms to increase the hiring of contract and temporary workers, for whom they need not provide benefits?

\section{Risks in Nonwage Benefits}

\section{Chapter 4: Health and coverage at risk}

Employee wages and salary are about 70 percent of compensation for private industry workers. Many of the risk-bearing aspects of compensation are connected with the nonwage 30 percent. Chapter 4 discusses changes in worker and retiree health insurance affecting worker risk bearing.

Health insurance plans in the United States are becoming less generous, with higher deductibles and higher copayments, they also cover a smaller percentage of the workforce. In this aspect of compensation, U.S. workers bear more risk than previously and bear greater risks than do Canadian workers. Because health insurance in the United States for individuals younger than age 65 is provided primarily through employers, loss of a job also often means loss of insurance. This connection makes job insecurity a more serious problem for older workers than for younger workers because the need for health insurance is greater for older workers. It also causes job insecurity to be a more serious problem in the United States than Canada.

In Canada, substantial health care benefits are provided through government programs. Many employers, however, provide supplementary health benefits. As the Canadian provincial governments struggle with the costs of medical care programs, employers are increasingly being asked to bear the cost of the benefits. Due to their 
own budgetary limitations, Canadian employers are incorporating cost containment features into their programs.

\section{Chapter 5: Risk sharing through social security retirement income systems}

Social security old-age benefits are an important aspect of employment-related risk bearing. They affect workers' risks with respect to their employment-related retirement income. The social security systems in Canada and the United States are similar in many important respects. They both are defined benefit systems with partial advance funding. They both provide benefits based on career average wageindexed earnings. They both provide modest benefits as compared with systems found generally in western Europe. An important difference between the two social security systems is that, in addition to earnings-related benefits, Canada provides non-earnings related benefits as an important part of the retirement income system. These demogrants are not provided in the United States. Because of these demogrants, the chapter characterizes the Canadian system as a fourtier retirement income system (demogrant, earnings-related social security benefits, private pensions, and private savings) while the U.S. retirement income system is generally characterized as a three-tier system (social security, private pensions, and private savings).

This chapter indicates that the Canadian social security system is generally more progressive than is the U.S. system, both in terms of financing and in terms of benefits. It generally provides better insurance against low earnings. For most women who have worked in paid employment, social security in Canada provides better survivors benefits, relative to benefits received while the spouse was alive, than it does in the United States.

\section{Chapter 6: Risk bearing in individual and occupational pension plans}

This chapter analyzes the trend towards workers bearing more risk in pension benefits in the United States and Canada and analyzes whether there is greater risk to pension benefits in the United States or Canada. 
Financial risk is inherent in pension plans. It must be borne-by workers, the employer, an insurance company, stockholders and bondholders of the company, taxpayers, or by other employers.

The rules that specify the conditions of benefit payment determine who bears pension risk. Some rules are explicit, determined by law, collective bargaining, or the pension benefit formula. Others are implicit, for example as to when the firm will provide cost-of-living adjustments to retirement benefits or terminate the pension plan.

Pension risks arise due to nondiversifiable investment risk in defined contribution plans and to variability in defined benefit liabilities caused by changing interest rates. Pension risks for workers arise due to uncertainty as to labor supply and demand, uncertainty as to life expectancy, inflation risk, and "political market" risks arising due to changing pension regulations. They also arise due to financial malfeasance in pension fund management.

Pensions also insure workers against risks. For example, an annuitized pension insures against the risks of outliving ones resources or of being unable to work in old age. As seen in this chapter, many employees are bearing more risk due to the change from defined benefit to defined contribution pension plans.

\section{Chapter 7: Risk shifting in workers' compensation}

Chapter 7 discusses changes in workers' compensation and how those changes affect risk bearing. Workers' compensation is financed by employers through premiums paid to insurance companies or through payroll taxes in jurisdictions where there is a monopoly state insurer. The ultimate incidence of at least part of these costs is passed on to workers in the form of compensating wage or benefit reductions. Thus, increased costs of workers' compensation associated with increased risk of injury or disease have always been borne to some extent by workers. An important question is, have pressures increased to shift a greater amount of risk associated with workplace injury and disease to workers?

There are reasons to believe they have. Intensified competition in product markets and freer mobility of capital resulting from increased foreign competition restrict the ability of employers to pass some costs of work injuries on to consumers in the form of higher prices. The full 
costs of workplace injuries may have been increasingly shifted to the factor of production whose mobility is largely circumscribed: labor.

In response to growing workers' compensation costs, legislators in both the United States and Canada have begun to limit both the availability of benefits and the magnitude of the generosity of the benefits that are awarded, with the effect of shifting costs more directly to workers. In both the United States and Canada, workers' compensation rules have restricted access to benefits for certain injuries. In Canada, a number of jurisdictions have reduced the income replacement rate for temporary and permanent partial disability benefits.

Workers' compensation arose out of a compromise in response to the uncertainty for both employers and workers of tort actions over work injuries. The no-fault system that evolved restricted the rights of workers to sue their employers for compensation of work injuries in return for adequate benefits paid with certainty. However, to the extent that regulators reduce the injuries and diseases that are covered by workers' compensation statues, possibilities open for increased litigation over workplace-related ailments.

\section{CONCLUSIONS}

This book analyzes many aspects of risk bearing by workers in Canada and the United Sates. Workers face many risks concerning their labor market earnings. Their compensation can vary due to variations in hours worked (including unemployment), real wage rates, and nonwage compensation and social insurance (such as pensions or health insurance). Within a given level of compensation, the insurance provided by employers can vary due to changes in the circumstances under which payments are received and the value of those payments. Employers can change the structure of pensions and (in the United States) health insurance or eliminate those benefits. The insurance protection provided by government may also vary, with changes in the provisions of social security programs and their levels of benefits.

Some of these factors affecting the level of financial risk workers bear fluctuate cyclically, others are subject to long-term trends, and others have both cyclical and trend elements to their variations. In the 
discussion in this book, an attempt is made to separate cyclical and short-run changes from trends and focus on the latter.

In addition, an attempt has been made to separate changes in worker behavior from changes in risks. For example, the labor force participation of women had become more like that of men, with an associated decrease in women's labor force turnover. This does not necessarily indicate that job risks for women have decreased. The evidence on job turnover for men suggests that job risks for older men have increased. Presumably, a similar effect for older women has been masked by their increasingly strong attachment to the labor force.

While not all trends affecting worker financial risk are moving towards greater financial risk bearing by workers, a number of trends are moving in that direction.

1) Job turnover has increased for older male workers. This is a group for whom involuntary job turnover is particularly expensive.

2) There has been a decline in insurance provided through nonwage compensation in the form of employer-provided health insurance in the United States and defined benefit pensions.

3) There has been a small increase in the percentage of workers in the contingent workforce.

4) Changes in social security have increased financial risk bearing by workers.

5) Many recent workers' compensation legislative reforms have caused workers to bear a greater direct burden of the costs of workplace injuries and illnesses.

The Canadian economy is greatly affected by changes in the U.S. economy. In Canada, however, the effects of job insecurity are less severe because of more generous unemployment benefits and because health insurance is not tied to employment.

While many hypotheses concerning causes and effects of changes in risk bearing have been discussed, and an attempt has been made to synthesize existing research on disparate subjects, this broad and complex subject eludes our full understanding. Much work remains for future researchers. 


\section{References}

Abraham, Katherine G., and Susan N. Houseman. 1993. Job Security in America: Lessons from Germany. Washington, D.C.: The Brookings Institution.

Bregger, John E. 1996. "Measuring Self-Employment in the United States." Monthly Labor Review January/February: 3-9.

Eberts, Randall W., and Joe A. Stone. 1992. Wage and Employment Adjustment in Local Labor Markets. Kalamazoo, Michigan: W.E. Upjohn Institute for Employment Research.

Feldstein, Martin. 1976. "Temporary Layoffs in the Theory of Unemployment." Journal of Political Economy 84(October): 937-958.

Gordon, Robert J. 1982. "Why U.S. Wage and Employment Behavior Differs from that in Britain and Japan." Economic Journal 92(December): 1344.

Gottschalk, Peter, and Robert Moffitt. 1994. "The Growth of Earnings Instability in the United States Labor Market." Brookings Papers on Economic Activity. 2: 217-254.

Gunderson, Morley, Douglas Hyatt, and James E. Pesando. 1996. "Public Pension Plans in the United States and Canada." Prepared for the W.E. Upjohn Institute Conference on Employee Benefits, Labor Costs, and Labor Markets in Canada and the United States, November 4-6, 1994.

Houseman, Susan N. 1995. "Job Growth and the Quality of Jobs in the U.S. Economy.” Staff working paper 95-39, W.E. Upjohn Institute for Employment Research, Kalamazoo, Michigan.

Millard, Stephen P. 1997. "The Effects of Increased Labour Market Flexibility in the United Kingdom: Theory and Practice." Unpublished manuscript, Bank of England.

Topel, Robert. 1984a. "Equilibrium Earnings, Turnover, and Unemployment." Journal of Labor Economics 2(October): 500-522.

. 1984b. "Experience Rating of Unemployment Insurance and the Incidence of Unemployment." Journal of Law and Economics 27(April): 61-90.

Verma, Anil, and Mark Thompson. 1988. "Managerial Strategies in Canada and the U.S. in the 1980s." In Industrial Relations Research Association Series: Proceedings of the Forty-first Annual Meeting, New York, December 28-30, pp. 257-264. 


\title{
Pay at Risk
}

\section{Compensation and Employment Risk in the United States and Canada}

\author{
John A. Turner
}

Editor

2001

W.E. Upjohn Institute for Employment Research

Kalamazoo, Michigan 


\section{Library of Congress Cataloging-in-Publication Data}

Pay at risk : compensation and employment risk in the United States and Canada / John A. Turner, editor.

p. cm.

Includes bibliographical references and index.

ISBN 0-88099-222-0 (cloth : alk. paper) - ISBN 0-88099-221-2 (paper : alk. paper)

1. Wage payment systems-United States. 2. Wage payment systems-Canada. 3 . Compensation management-United States. 4. Compensation management-Canada. 5. Labor economics-United States. 6. Labor economics-Canada. 7. Employee fringe benefits-Finance. 8. Social security-Finance. 9. Old age pensions-Finance. 10. Insurance, Health-Finance. 11. Job security. I. Turner, John A.

HD4927.U6 P39 2001

$331^{\prime} .0971-\mathrm{dc} 21$

2001023606

(C) 2001

W.E. Upjohn Institute for Employment Research

$300 \mathrm{~S}$. Westnedge Avenue

Kalamazoo, Michigan 49007-4686

The facts presented in this study and the observations and viewpoints expressed are the sole responsibility of the authors. They do not necessarily represent positions of the W.E. Upjohn Institute for Employment Research.

Cover design by J.R. Underhill.

Index prepared by Diane Worden.

Printed in the United States of America. 